\author{
ANNA SZCZEPAŃSKA-DUDZIAK \\ Uniwersytet Szczeciński \\ ORCID: 0000-0003-4596-0956
}

\title{
Dyplomacja gospodarcza Polski w relacjach z Azerbejdżanem w latach 2006-2015
}

\section{Polish economic diplomacy in relations with Azerbaijan from 2006 to 2015}

\begin{abstract}
The article deals with Polish economic diplomacy in its relations with Azerbaijan between 2006 and 2015. It also analyses the system for the promotion of the economy and support for Polish enterprises. It examines the institutional and legal framework during the period of the economic diplomacy reform initiated in 2006, along with the forms of support for Polish exports and investments in the difficult market which required action from the Polish authorities. The results of the study indicate that although Poland perceives Azerbaijan as its most important economic partner in the South Caucasus and sees a great potential for mutual collaboration, the activities of the Polish Embassy in Baku were strengthened neither in terms of personnel nor substantively. There was also no increase in trade and Polish investments.
\end{abstract}

Keywords: Polish economic diplomacy, foreign economic policy, Azerbaijan

Słowa kluczowe: dyplomacja gospodarcza Polski, zagraniczna polityka ekonomiczna, Azerbejdżan

\section{Wprowadzenie}

Zapewnienia o szczególnym znaczeniu Azerbejdżanu jako najważniejszego partnera Polski na Kaukazie Południowym wielokrotnie padały z ust polskich prezydentów, szefów dyplomacji oraz ministrów gospodarki odwiedzających lub przyjmujących z rewizytą azerbejdżańskich polityków. Liczne spotkania na szczeblu państwowym, ministerialnym, a także misje gospodarcze z udziałem przedsiębiorców nie przełożyły się jednak na wielkość obrotów 
handlowych i znaczącą obecność polskich firm na tamtym rynku. Powstaje zatem pytanie, dlaczego intensywne zabiegi polityków wsparte działaniami polskiej dyplomacji nie przynoszą rezultatów odzwierciedlających potencjał i możliwości współpracy gospodarczej obu państw. Odpowiedzi należy szukać w konglomeracie problemów, na który składają się zmienna koniunktura gospodarcza, odległość geograficzna i wynikające z niej trudności transportowo-komunikacyjne, niewielkie doświadczenia we współpracy, nieznajomość rynku partnera oraz niepewne warunki inwestycyjne, na które napotykają potencjalni eksporterzy lub inwestorzy zainteresowani Azerbejdżanem. Na skalę trudności, jakim przychodzi im stawić czoła - działania monopolistyczne, niejasne ustawodawstwo oraz korupcję, wywołujące niepewność i niechęć do podejmowania współpracy - zwracały uwagę ekspertki przygotowujące jedyny jak dotąd pełen przewodnik po rynku Azerbejdżanu przeznaczony dla polskich eksporterów i inwestorów ${ }^{1}$. Podobny obraz potencjalnego partnera gospodarczego wyłaniał się z opublikowanego na stronie polskiego Ministerstwa Spraw Zagranicznych informatora poświęconego różnicom kulturowym w międzynarodowych relacjach biznesowych. W odnoszącym się do Azerbejdżanu fragmencie publikacji wydanej pod auspicjami Departamentu Współpracy Ekonomicznej MSZ pisano: „Nie rekomendujemy działalności inwestycyjnej, chyba że polski podmiot ma zaufanie do miejscowego partnera. Powodzenie działalności biznesowej - przynajmniej na początkowym etapie - wymaga posiadania miejscowego pracownika zorientowanego w miejscowych realiach"2.

W strukturze Ambasady RP w Baku nigdy nie istniał Wydział Promocji Handlu i Inwestycji (WPHI). Miało to istotny wpływ na poziom aktywności placówki w promowaniu polskiej gospodarki i możliwości udzielania wsparcia

1 Azerbejdżan. Przewodnik dla przedsiębiorców, oprac. A. Naruniec, E. Fischer, Biuro Promocji Inwestycji i Technologii Organizacji Narodów Zjednoczonych ds. Rozwoju Przemysłowego UNIDO, Warszawa 2006. Zob. też: Informacje praktyczne dla polskiego eksportera - Azerbejdżan, „Portal Promocji Eksportu” [online], 18 VIII 2017 [dostęp: 21 III 2018], dostępny w internecie: <https://www.trade.gov.pl/pl/analizy-rynkowe/ azja/azerbejdzan/227549, informacje-praktyczne-dla-polskiego-eksportera-azerbejdzan. html $>$. Na temat sytuacji w Azerbejdżanie i tamtejszych warunków inwestycyjnych zob. K. Zasztowt, Azerbejdżan po dekadzie rządów prezydenta Ilhama Aliyeva, Polski Instytut Spraw Międzynarodowych, 4 IX 2013 (Biuletyn PISM, 90 (1066)).

2 Różnice kulturowe w międzynarodowych relacjach biznesowych, Departament Współpracy Ekonomicznej Ministerstwa Spraw Zagranicznych, Warszawa 2017, s. 236, dostępny w internecie [dostęp: 17 X 2019]: <https://www.msz.gov.pl/pl/p/msz_pl/polityka_zagraniczna/dyplomacja_biznes/wydarzenia/informator_o_roznicach_kulturowych_w_miedzynarodowych_relacjach_biznesowych?channel=www $>$. 
przedsiębiorcom. W myśl zawartego 7 lutego 2006 r. porozumienia między ministrem spraw zagranicznych oraz ministrem gospodarki w sprawie ustanowienia dyplomacji ekonomicznej to właśnie WPHI realizowały działania promocyjno-informacyjne na rzecz zapewnienia polskim towarom i usługom dostępu do rynków zagranicznych, dostarczały polskim eksporterom informacje o rynkach kraju urzędowania i prowadziły działalność doradczą na rzecz małych i średnich przedsiębiorstw ${ }^{3}$. Warto zatem podjąć próbę odpowiedzi na pytanie, w jaki sposób polska dyplomacja gospodarcza realizowała swoje zadania $\mathrm{w}$ relacjach z Azerbejdżanem oraz czy wykorzystywane przez nią instrumentarium mogło mieć istotny wpływ na zwiększenie stosunkowo niskiego poziomu współpracy handlowej i inwestycyjnej z tym krajem.

Z perspektywy czasu i doświadczeń współpracy dwustronnej wydaje się, że skutecznymi sposobami na zwiększenie obecności gospodarczej Polski w Azerbejdżanie są wsparcie ze strony instytucji państwowych, współpraca na szczeblu rządowym i ministerialnym oraz skuteczne działania dyplomatów ${ }^{4}$. W przypadku państw, gdzie administracja rządowa ma kluczowe znaczenie w nawiązywaniu kontaktów gospodarczych, a takim jest Azerbejdżan, aktywność rządu i dyplomacji stanowi dla eksporterów i inwestorów z Polski najważniejsze wsparcie. Uczestniczący w misji gospodarczej do Azerbejdżanu szef Polskiej Agencji Informacji i Inwestycji Zagranicznych (PAIiIZ) Sławomir Majman mówił:

Tego rodzaju misje mają wykorzystać przedstawiciela władzy wykonawczej jako lodołamacz, jako kogoś, kto otwiera drzwi dla przedsiębiorców albo pomaga im się wspiąć na taki szczebel, jaki byłby nie do pomyślenia bez premiera, ministra czy innego wyższego urzędnika. Te wyprawy mają szczególny sens w krajach, gdzie bardzo przeplata się polityka i gospodarka ${ }^{5}$.

3 Analiza roli i znaczenia wydziałów promocji handlu i inwerstycji oraz wydziałów ekonomicznych przy ambasadach na podstawie badań empirycznych: O. Augustynowicz, M. Bartosik-Purgat, Rola placówek ekonomiczno-dyplomatycznych $w$ działalności eksportowej polskich przedsiębiorstw - perspektywa placówek i przedsiębiorstw, „Handel Zagraniczny" 2015, nr 5, s. 24-36.

4 Zob. przesłuchanie kandydata na ambasadora RP w Azerbejdżanie Michała Łabendy: „Biuletyn z posiedzenia Komisji Spraw Zagranicznych (nr 175)” 2010, nr 3974/VI kad., dostępny w internecie [dostęp: 17 X 2019]: <http://orka.sejm.gov.pl/Biuletyn.nsf/0/ A6C3B845717FBCD3C125776900483C27/\$file/0397406.pdf>.

5 Prezes PAIiIZ brał udział w misji ministra gospodarki Janusza Piechocińskiego do Azerbejdżanu w czerwcu 2015 r. M. Zabłocki, Polska i Azerbejdżan zwiększa handel, „Bankier" [online], 3 VI 2015 [dostęp: 17 X 2019], dostępny w internecie: <https://www. bankier.pl/wiadomosc/Polska-i-Azerbejdzan-zwieksza-handel-3354958.html>. 
Podjęty tu temat badawczy jest ważny zarówno ze względu na bilateralne relacje Warszawy z Baku i rolę problematyki gospodarczej w ich dalszym rozwoju, jak też z uwagi na zachodzące właśnie zmiany w funkcjonowaniu dyplomacji ekonomicznej Polski. Podstawą do wyznaczenia cezury czasowej artykułu był rozpoczęty w 2006 r. proces ekonomizacji polskiej dyplomacji, który przechodzi aktualnie gruntowne zmiany strukturalne i personalne, zapowiedziane w 2016 r. przez rząd Prawa i Sprawiedliwości ${ }^{6}$. Warto w tej sytuacji dokonać podsumowania działań instytucji odpowiedzialnych za rozwój współpracy gospodarczej, zwiększenie polskiej obecności inwestycyjnej oraz promocję polskiej gospodarki za granicą. Za przykład mogą posłużyć działania polskiej dyplomacji w odniesieniu do Republiki Azerbejdżanu - początkowo mało znaczącego partnera, który został uznany za jeden z perspektywicznych rynków z punktu widzenia interesów gospodarczych Polski.

Analizie poddane zostały zarówno instrumenty zależnej od Ministerstwa Spraw Zagranicznych dyplomacji ekonomicznej, jak też aktywność Ministerstwa Gospodarki i podległych mu struktur w zakresie promocji polskiego eksportu i inwestycji w Azerbejdżanie w latach 2006-20157. Spośród funkcjonujących

6 W ogłoszonym w 2016 r. „Planie na Rzecz Odpowiedzialnego Rozwoju” zapowiedziano przeprowadzenie reformy organizacyjnej dyplomacji gospodarczej. W 2017 r. w miejsce Polskiej Agencji Informacji i Inwestycji Zagranicznych powstała Polska Agencja Handlu i Inwestycji, po czym rozpoczęto tworzenie podległych jej Zagranicznych Biur Handlowych, Ustawa z dnia 7 lipca 2017 r. o wykonywaniu zadań z zakresu promocji gospodarki przez Polska Agencję Inwestycji i Handlu Spółka Akcyjna, Dz.U. 2017, poz. 1491. W maju 2018 r. zamknięto ostatni WPHI.

7 Zadania dyplomacji gospodarczej Polski w okresie powojennym realizowały biura radcy handlowego, które w 1999 r. przekształcono w wydziały ekonomiczno-handlowe ambasad. Zapowiedzi ekonomizacji polskiej polityki zagranicznej pojawiały się wielokrotnie od końca lat osiemdziesiątych, kiedy doszło do utworzenia Agencji ds. Inwestycji Zagranicznych. Por. M. Przeperski, Ostatnia próba modernizacji PRL. Rząd Mieczysława F. Rakowskiego (1988-1989), „Pamięć i Sprawiedliwość” 2016, nr 1 (27), s. 212. Myśl ta powróciła w okresie przygotowań akcesyjnych do Unii Europejskiej, m.in. w sejmowych exposé ministra spraw zagranicznych Włodzimierza Cimoszewicza w 2002 i 2003 r., a kilka lat później realnych kształtów nadał jej minister Stefan Meller. Projekt ekonomizacji polskiej polityki zagranicznej określony został w dokumencie programowym rządu Kazimierza Marcinkiewicza: ,, Solidarne Państwo”. Program działania rządu premiera Kazimierza Marcinkiewicza, Warszawa 2005. Zob. też: Porozumienia z 7 lutego 2006 r. między Ministrem Spraw Zagranicznych a Ministrem Gospodarki w sprawie ustanowienia dyplomacji ekonomicznej, „Biuletyn Prasowy” (Ministerstwo Gospodarki) 2006, nr 7; Porozumienia z 14 września 2006 r. między Ministrem Spraw Zagranicznych a Ministrem Gospodarki w sprawie wspótpracy w realizacji dzialań Ministra Gospodarki z zakresu promocji handlu i inwestycji zagranicznych przez polskie placówki zagraniczne, w których nie funkcjonują Wydziały Promocji Handlu i Inwestycji, „Biuletyn Prasowy” (Ministerstwo Gospodarki) 2006, nr 7; Materiat informacyjny na posiedzenie Komisji Gospodarki Narodowej Senatu RP w sprawie efektywności promowania polskiej gospodarki w świecie. Informacja o działaniach MSZ na rzecz 
w literaturze przedmiotu terminów określających narzędzia realizacji zagranicznej polityki ekonomicznej - dyplomacja ekonomiczna, dyplomacja gospodarcza i dyplomacja handlowa - autorka wybrała termin dyplomacja gospodarcza, idąc za Edwardem Molendowskim i Wojciechem Polanem. Jest on szerszy niż dyplomacja ekonomiczna, rozumiana jako działania podejmowane przez podmioty państwowe i na rzecz podmiotów państwowych ${ }^{8}$.

wzmocnienia wizerunku gospodarczego kraju za granica, Departament Dyplomacji Ekonomicznej MSZ, [Warszawa 2009], dostępny w internecie [dostęp: 14 VII 2014]: <http://ww2. senat.pl $/ \mathrm{k} 7 / \mathrm{kom} / \mathrm{kgn} / \mathrm{g} / 8 . \mathrm{pdf}>$. Szerzej na temat powstania polskiej dyplomacji ekonomicznej: G. Gawin, Ksztaltowanie się i rola dyplomacji ekonomicznej w Polsce, „Polski Przegląd Dyplomatyczny" 2008, nr 3 (43), s. 101-118; A. Szczepańska, Dyplomacja ekonomiczna Polski 2006-2008, [w:] W kręgu idei, polityki i wojska. Studia dedykowane Profesorowi Januszowi Farysiowi w siedemdziesiąta rocznicę urodzin, red. T. Sikorski, H. Walczak, A. Wątor, Wydawnictwo Naukowe Uniwersytetu Szczecińskiego, Szczecin 2009, s. 451-463; A. Szczepańska-Dudziak, Dyplomacja ekonomiczna Polski na Wschodzie, [w:] Dylematy polityki zagranicznej Polski na poczatku XXI wieku, red. K. Czornik, M. Lakomy, M. Stolarczyk, Wydawnictwo Uniwersytetu Śląskiego, Katowice 2014, s. 321-341; H. Dumała, Dyplomacja ekonomiczna - założenia i realizacja, [w:] Nowe oblicza dyplomacji, red. B. Surmacz, Wydawnictwo Uniwersytetu Marii Curie-Skłodowskiej, Lublin 2013, s. 253-276; B. Surmacz, Ewolucja wspótczesnej dyplomacji. Aktorzy, struktury, funkcje, Wydawnictwo Uniwersytetu Marii Curie-Skłodowskiej, Lublin 2015, s. 250-253; Rola i zaangażowanie instytucji publicznych w promocję gospodarcza Polski i regionów (wystapienie $R$. Wiśniewskiego, Wiceministra SZ RP), dostępne w internecie [dostęp: 17 X 2019]: <https://www.paih. gov.pl/files/?id_plik=7520>; P. Zerka, Instrumentarium dyplomacji ekonomicznej: wyzwania i dylematy. Materiat na trzecie spotkanie z serii „Polska w świecie 2030. Globalizacja polskiej polityki zagranicznej i europejskiej”, Demos Europa, [Warszawa] 2012.

8 Rozważania definicyjne na temat dyplomacji gospodarczej i handlowej oraz zakres pojęciowy: R. Hryniewiecki, K. Borońska, Dyplomacja gospodarcza jako nowe narzędzie polityki zagranicznej państwa, [w:] Ekonomia 12 - problemy globaliza$c j i$, red. J. Rymarczyk, Wydawnictwo Uniwersytetu Ekonomicznego we Wrocławiu, Wrocław 2010, dostępny w internecie [dostęp: 17 X 2019]: <https://www.academia. edu/5070783/Dyplomacja_gospodarcza_jako_narz\%C4\%99dzie_polityki_zagranicznej_pa\%C5\%84stwa_2011_Ekonomia_12_Problemy_globalizacji?auto=E. Molendowski, W. Polan, Dyplomacja gospodarcza - rola $i$ znaczenie w polityce zagranicznej państwa, Wolters Kluwer Polska, Warszawa 2007, s. 64-65; E. Molendowski, Dyplomacja gospodarcza Polski: organizacja, główne zadania w okresie transformacji, [w:] Handel zagraniczny i biznes międzynarodowy we współczesnej gospodarce, red. M. Maciejewski, K. Wach, Wydawnictwo Naukowe Uniwersytetu Ekonomicznego w Krakowie, Kraków 2017, s. 451-455, dostępny w internecie [dostęp: 17 X 2019]: $<$ https://www.researchgate.net/publication/322405623_Dyplomacja_gospodarcza_Polski_organizacja_glowne_zadania_w_okresie_transformacji $>$; J. Pinder, Economic diplomacy, [w:] World politics. An introduction, ed. J.N. Rosenau, K. W. Thompson, G. Boyd, New York 1976; C. Ford, Commercial diplomacy. The next wave, „Foreign Service Journal" 2005, vol. 82 (2), s. 24-27; R. Saner, L. Yiu, International economic diplomacy. Mutations in Post-modern times, „Clingendael Discussion Papers in Diplomacy” 2003, No. 84, s. 12-14, dostępny w internecie [dostęp: 17 X 2019]: <https://www.clingendael. org/publication/international-economic-diplomacy-mutations-post-modern-times $>$. 
Podstawę źródłową rozważań stanowią dokumenty oraz informacje prasowe odnoszące się do struktur i instrumentów dyplomacji ekonomicznej oraz działalności MG i podległych mu instytucji odpowiedzialnych za promocję polskiej gospodarki, a także prezentujące działania polskiej dyplomacji wobec Azerbejdżanu, zwłaszcza w kontekście gospodarczym. Dzięki funkcjonowaniu dyplomacji cyfrowej źródłem informacji o działalności Ambasady RP w Baku stały się jej strona internetowa (w tym biuletyny), jak też strona internetowa polskiego Sejmu, MSZ i MG .

Podjęty temat nie był do tej pory przedmiotem odrębnych zainteresowań badawczych, które znalazłyby odzwierciedlenie w literaturze przedmiotu. Jedynym wyjątkiem jest artykuł Krystyny Gomółki pt. Wymiana handlowa Polski $z$ Armenia, Azerbejdzanem i Gruzja ${ }^{10}$. Nieco szersze grono badaczy zajmuje się natomiast polską dyplomacją ekonomiczną - ewolucją jej form oraz zadań. Na uwagę zasługują także inicjatywa zorganizowania w latach 2012-2014 konferencji naukowych oraz towarzyszące im publikacje poświęcone relacjom dwustronnym Polski i Azerbejdżanu ${ }^{11}$.

\section{Miejsce Azerbejdżanu w zagranicznej polityce ekonomicznej Polski}

Azerbejdżan jako jedno z państw Kaukazu Południowego jest dziś obszarem zainteresowania Unii Europejskiej objętym Europejską Polityką Sąsiedztwa i Partnerstwem Wschodnim. Jego regionalne i globalne znaczenie wynika zarówno z geograficznego usytuowania na strategicznym szlaku komunikacyjnym między Europą a Azją, jak również z faktu, że jest to państwo o największym potencjale demograficznym i ekonomicznym w regionie, posiadające zasoby naturalne gazu ziemnego i ropy naftowej.

Dążenie Polski do dywersyfikacji źródeł oraz szlaków dostaw surowców czyni Azerbejdżan atrakcyjnym partnerem do współpracy gospodarczej.

9 Autorka nie uzyskała dostępu do informacji dotyczących działalności Wydziału Ekonomicznego placówki w Azerbejdżanie pomimo próśb kierowanych w kwietniu i maju 2018 r. do Ambasady RP w Baku, Departamentu Wschodniego oraz Departamentu Współpracy Ekonomicznej MSZ RP.

10 K. Gomółka, Wymiana handlowa Polski z Armenia, Azerbejdżanem i Gruzja, „Acta Politica" 2014, nr 29, s. 5-16.

11 Materiały z I, II i III konferencji naukowej poświęconej 540-leciu nawiązania i 20-leciu odnowienia stosunków dyplomatycznych między Azerbejdżanem a Polską opublikowano w 2012 i 2014 r. w Warszawie: S. Alijewa, Partnerstwo strategiczne Republiki Azerbejdżanu i Rzeczypospolitej Polskiej, [w:] Materiaty III konferencji naukowej poświęconej 540-leciu nawiązania oraz 20-leciu odnowienia stosunków dyplomatycznych między Azerbejdżanem a Polska, Oficyna „Olszynka”, Warszawa 2014, s. 36-42. 
Relacje dwustronne obu krajów mają ponad pięćsetletnią tradycję i pozytywne konotacje historyczne wzmocnione obecnością Polaków w tym państwie i ich wkładem w jego rozwój ${ }^{12}$. W XX w. nawiązywano je dwukrotnie po raz pierwszy w 1918, a ponownie po rozpadzie ZSRR - w 1992 r., kiedy to Polska jako jedna z pierwszych uznała podmiotowość Azerbejdżanu. Powolna budowa struktur tego państwa i realizacja w pierwszej kolejności priorytetowych celów polityki zagranicznej spowodowały, że przedstawicielami dyplomatycznymi RP byli tam początkowo ambasadorowie w Turcji (Wojciech Hansel, a następnie Mirosław Pałasz). Polska ambasada w Baku rozpoczęła działalność dopiero 21 września 1998 r., pod kierownictwem Stanisława Stawiarskiego w randze chargé d'affaires ${ }^{13}$.

Pomimo krótkiego okresu wzajemnych kontaktów szybko udało się je ująć w formy traktatowe. Najważniejszą rolę odgrywały w nich kwestie gospodarcze, o czym świadczy wizyta prezydenta Azerbejdżanu w Polsce, podczas której podpisano szereg dwustronnych umów regulujących współpracę handlową i inwestycyjną ${ }^{14}$. Pod koniec lat dziewięćdziesiątych, podczas wizyty Aleksandra Kwaśniewskiego w Baku, po raz pierwszy wprowadzono do programu rozmów komponent gospodarczy. Prezydentowi towarzyszyli wtedy przedstawiciele firm Budimex, Kamax, Metalexport, Metronex, Roblo, Forcan i Polimex-Cekop ${ }^{15}$.

Wyzwaniem dla pierwszego polskiego ambasadora w Azerbejdżanie Marcina Nawrota był brak stabilności politycznej tego kraju oraz konflikty zbrojne wpływające na sytuację w całym regionie ${ }^{16}$. Realizacji strategicznego interesu Polski ambasador upatrywał w budowie rurociągu

12 A.J. Chodubski, Azerbejdżan - Polska. Odsłony kontaktów kulturowych, Wydawnictwo „Adam Marszałek”, Torun 2015, s. 65-243.

13 K. Szczepanik, Dyplomacja Polski 1918-2000 - struktury organizacyjne, Akson, Warszawa 2000, s. 188; Stosunki dyplomatyczne Polski. Informator, t. 3: Azja, Zakaukazie, Australia, Oceania 1918-2009, red. K. Szczepanik, A. Herman-Łukasik, B. Janicka, Akson, Warszawa 2010, s. 32-33.

14 Podpisano je 26 VIII 1997 r. Tamże, s. 36. Nowa umowa o współpracy gospodarczej zawarta została 30 III $2005 \mathrm{r}$.

15 Azerbejdżan. Przewodnik..., s. 101-102. We wrześniu 2000 r. do Azerbejdżanu pojechał wraz z grupą biznesmenów minister gospodarki, pracy i polityki społecznej. Rozmowy dotyczyły współpracy przy wydobyciu ropy, budowy gazociągów i cukrowni oraz zakupu polskiej żywności.

16 Przesłuchanie kandydata na ambasadora RP w Azerbejdżanie Marcina Nawrota: „Biuletyn z posiedzenia Komisji Spraw Zagranicznych (nr 153)” 2001, nr 4096/III kad., dostępny w internecie [dostęp: $17 \mathrm{X}$ 2019]: <http://orka.sejm.gov.pl/Biuletyn.nsf/0/84E45CC9D767E5B9C1256B73003DD103?OpenDocument>. Misję dyplomatyczną w Baku pełnił w latach 2001-2005. 
Baku-Supsa-Odessa-Brody-Gdańsk, który pozwalałby na tranzyt środkowoazjatyckiej ropy naftowej przez terytorium Polski. Sposobem osiągnięcia tego celu miał być udział naszego kraju w realizacji unijnych planów stworzenia szlaku transportowego Europa-Kaukaz-Azja (TRACECA), tj. odbudowie połączeń komunikacyjnych między Europą i Azją, zapewnieniu dywersyfikacji źródeł ropy i gazu oraz ich transportu do Europy (program INOGATE). Jako kandydat na ambasadora w Baku Nawrot realistycznie oceniał możliwości kreowania sytuacji w rejonie przez Rzeczpospolitą (,,udział Polski w polityce tamtego regionu jest raczej bierny"), a jednocześnie wskazywał obiecujące obszary rozwoju wpływów i zwiększenia korzyści gospodarczych „poprzez nie tylko wymianę doświadczeń, ale także przez udział naszych technologii w rozwoju przemysłu azerskiego. Takie działania już zostały podjęte, na razie w sferze deklaracji i porozumień. Czekamy na ich spożytkowanie. Nasza placówka w Baku może odegrać w tej kwestii pewną rolę"17. Rozpad ZSRR i zerwanie części ekonomicznych powiązań Azerbejdżanu oraz odcięcie go od dostaw surowców i półfabrykatów z państw postsowieckich na skutek wojen karabaskiej i czeczeńskiej stwarzały zdaniem ambasadora szanse dla polskich technologii i doświadczenia w budowie rurociągów.

Zainteresowanie Warszawy skupiało się na surowcowym i tranzytowym potencjale Azerbejdżanu, co stało się jeszcze bardziej widoczne po wejściu Polski do Unii Europejskiej w 2004 r. i równoczesnym objęciu tego państwa Europejską Polityką Sąsiedztwa. Interes gospodarczy Polski był główną wytyczną misji dyplomatycznej ambasadora Krzysztofa Krajewskiego (2005-2010), który zabiegał o tranzyt azerskiej ropy na zachód przez terytorium Polski i zwiększenie wzajemnej wymiany handlowej ${ }^{18}$. Swój pobyt w Baku rozpoczynał w okresie intensyfikacji kontaktów polsko-azerbejdżańskich, której efektem było podpisanie w marcu 2005 r. kilku umów na szczeblu rządowym i ministerialnym, rozszerzających współpracę gospodarczą ${ }^{19}$. Ambasada w Baku odgrywała ważną rolę w realizacji rządowego celu, jakim była poprawa bezpieczeństwa energetycznego Polski poprzez dywersy-

17 Tamże.

18 Ambasador wymienił jeszcze trzy priorytety swoich działań: współpracę polityczną, troskę o zwiększenie aktywności Polonii i promocję polskiej kultury, a w szczególności języka polskiego. Przesłuchanie kandydata na ambasadora RP w Azerbejdżanie Krzysztofa Krajewskiego: „Biuletyn z posiedzenia Komisji Spraw Zagranicznych (nr 238)” 2005, nr 4465/IV kad., dostępny w internecie [dostęp: 17 X 2019]: <http://orka.sejm.gov.pl/ Biuletyn.nsf/0/32153D16D280A7C0C1256FF8003ED1BB?OpenDocument>.

19 Stosunki dwustronne, „Ambasada Republiki Azerbejdżanu w Rzeczypospolitej Polskiej” [online], 29 II 2016 [dostęp: 17 X 2019], dostępny w internecie: <http://warsaw.mfa.gov. $\mathrm{az} / \mathrm{pl} /$ content/3>. 
fikację źródeł dostaw ropy naftowej, a działający w jej strukturze Wydział Ekonomiczny wspomagał rząd w pozyskiwaniu dostawców z regionu Morza Kaspijskiego $^{20}$. Rozważano wtedy także utworzenie w placówce stanowiska radcy handlowego, a pracownik odpowiadający za sprawy gospodarcze (jak należy domniemywać) niewątpliwie wzmocniłby jej obsadę kadrową ${ }^{21}$.

\section{Promocja polskiej gospodarki}

W 2006 r. rozpoczął się proces ekonomizacji polskiej polityki zagranicznej, co widać było także w relacjach z Azerbejdżanem. Celem strategicznym tej koncepcji stała się ekspansja zagraniczna polskich firm, dlatego też problematykę ekonomiczną włączano do agendy spotkań przywódców państw i dyplomatów, a w podróżach i misjach zagranicznych brali udział przedsiębiorcy. 6-8 kwietnia 2006 r. Piotr Woźniak jako drugi polski minister gospodarki złożył wizytę w Azerbejdżanie ${ }^{22}$. Rozmawiał wówczas z prezydentem, premierem oraz ministrem przemysłu i energetyki tego kraju na temat współpracy w dziedzinie energetyki, rolnictwa, poligrafii, budowy dróg i infrastruktury komunalnej, a także o projekcie Odessa-Brody ${ }^{23}$. We wrześniu 2006 r. zainaugurowała pracę Wspólna Komisja ds. Współpracy Gospodarczej między Polską a Azerbejdżanem, która do dziś stanowi jeden z najważniejszych mechanizmów regulujących dwustronną współpracę ${ }^{24}$.

Jednym ze sposobów promowania polskiej gospodarki na rynku azerbejdżańskim był udział polskich przedsiębiorstw w odbywających się tam targach i wystawach. W listopadzie 2006 r. podczas wizyty marszałka Senatu RP Bogdana Borusewicza otwarta została Polska Wystawa Narodowa (w 2007 r. zorganizowano drugą edycję) $)^{25}$. Przy dużym wsparciu ze strony polskich

20 Dyplomacja ekonomiczna. Pierwszy rok działania, Departament Zagranicznej Polityki Ekonomicznej MSZ, Warszawa, czerwiec 2007, w zbiorach autorki.

21 Azerbejdżan. Przewodnik..., s. 101.

22 Przed nim we wrześniu 2000 r. udał się tam Janusz Steinhoff.

23 MG: Azerbejdżan chce wspótpracować z Polska w dziedzinie gospodarki, „Puls Biznesu” [online], 10 IV 2006 [dostęp: 17 X 2019], dostępny w internecie: <https://www.pb.pl/ mg-azerbejdzan-chce-wspolpracowac-z-polska-w-dziedzinie-gospodarki-310205>.

24 Stosunki dwustronne..., a także informacja I sekretarza ambasady RP w Baku z 17 IX 2018 r. na zapytanie złożone przez autorkę.

25 Wizyta Marszatka Senatu RP w Azerbejdżanie „Ambasada Rzeczypospolitej Polskiej w Baku” [online], 23 XII 2006 [dostęp: 17 X 2019], dostępny w internecie: <https://baku.msz.gov. $\mathrm{pl} / \mathrm{pl} / /$ aktualnosci/archiwum/2006/>; Polska Wystawa Narodowa w Azerbejdżanie, „Ambasada Rzeczypospolitej Polskiej w Baku" [online], 23 XII 2006 [dostęp: 17 X 2019], dostępny w internecie: <https://baku.msz.gov.pl/pl//aktualnosci/archiwum/2006/>. W dniach 8-10 XI 2006 r. marszałkowi senatu towarzyszyli m.in. przedstawiciele Lotosu i Orlenu. 
dyplomatów w Azerbejdżanie wzięło w niej udział czterdzieści polskich firm z branż spożywczej, kosmetycznej, budowlanej i elektrycznej. Warto dodać, że od 2004 r. MG udzielało dofinansowania kosztów uczestnictwa w targach i wystawach promocyjnych o charakterze proeksportowym ${ }^{26}$. W 2006 r. wydarzenia organizowane w Azerbejdżanie znalazły się na liście targów priorytetowych, a polscy przedsiębiorcy, którzy chcieli działać na tym rynku, uzyskali dodatkowo gwarancje Korporacji Ubezpieczeń Kredytów Eksportowych zabezpieczające ich pozycję w kraju o podwyższonym ryzyku ${ }^{27}$. Od 2007 r. na liście B targów o priorytetowym znaczeniu dla gospodarki Polski, w których uczestnictwo objęte jest dofinansowaniem w ramach Sektorowego Programu Operacyjnego „Wzrost Konkurencyjności Przedsiębiorstw”, znajduje się pięć imprez organizowanych w Azerbejdżanie: Baku Build, BIHE, Xazarneftgaz, Inter Food Azerbejdjan, Baku Mebel ${ }^{28}$.

Działania na rzecz promocji gospodarczej Polski zostały też określone w rządowym programie Założenia Promocji Gospodarki Polskiej 2007-2015, którego hasło przewodnie brzmiało: „Polska uznanym partnerem gospodarczym, atrakcyjnym partnerem pod względem inwestycyjnym i turystycznym"29. Celem strategii było zwiększenie znaczenia Polski w gospodarce międzynarodowej, poprawa wizerunku gospodarki i jej umiędzynarodowienie. Tak określone zadania polskiej polityki zagranicznej były tożsame z działaniami prowadzonymi w ramach polityki gospodarczej i energetycznej Unii Europejskiej. W 2007 r. UE i Azerbejdżan stały się partnerami strategicznymi w zakresie energetyki. Z punktu widzenia interesów Polski i jej bezpieczeństwa

26 Formy promocji eksportu, zasady i tryb finansowania udziału przedsiębiorców w targach i wystawach za granicą regulowało Rozporzadzenie Ministra Gospodarki i Pracy z 15 października 2004 r. w sprawie pomocy de minimis przedsiębiorcom uczestniczacym w targach $i$ wystawach za granica, Dz.U. 2004, nr 233, poz. 2342. Zob. także: Odpowiedź podsekretarz stanu w Ministerstwie Gospodarki [Ilony Antoniszyn-Klik] - z upoważnienia ministra na interpelację poselska $n r 14588$ w sprawie konieczności stworzenia systemu promocji polskiej gospodarki $i$ wspierania za granica polskich przedsiębiorstw, „Sejm Rzeczypospolitej Polskiej" [online], 13 III 2013 [dostęp: 17 X 2019], dostępny w internecie: <http:// www.sejm.gov.pl/sejm7.nsf/InterpelacjaTresc.xsp?key=4EB50AD6>.

27 Azerbejdżan. Przewodnik..., s. 103; Raport roczny za rok 2006, „KUKE” [online, dostęp: 15 VII 2008], dostępny w internecie: <http://www.kuke.com.pl/raport_roczny/ch_05 pl.html>; Wspieranie eksportu, rynki zagraniczne, „Eksporter” [online, dostęp: 14 VII 2008], dostępny w internecie: <www.eksporter.gov.pl>. Realizacją postanowień zajmował się Departament Instrumentów Wsparcia Ministerstwa Gospodarki, który nadzorował działania zlecone przez Polską Agencję Informacji i Inwestycji Zagranicznych, Polską Agencję Rozwoju Przedsiębiorczości oraz Korporację Ubezpieczeń Kredytów Eksportowych.

28 „Biuletyn Prasowy Ministerstwa Gospodarki” 2007, nr 65.

29 Założenia do Strategii Promocji Gospodarki Polskiej 2007-2015, Ministerstwo Gospodarki, Warszawa 2007. 
energetycznego ważną rolę odgrywały współpraca w ramach Euroazjatyckiego Korytarza Transportu Ropy Naftowej (Odessa-Brody-Gdańsk) oraz możliwość stworzenia Południowego Korytarza Energetycznego. Problemy te zdominowały agendę rozmów podczas wizyt prezydenta Lecha Kaczyńskiego w Azerbejdżanie w 2007 i 2009 r. ${ }^{30}$ Ich efektem było podpisanie przez spółki Lotos i Socar listu intencyjnego w sprawie wydobycia i przerobu ropy naftowej, która miała być tłoczona do Polski rurociągiem Odessa-Brody ${ }^{31}$.

Od 2010 r. cele polskiej polityki zagranicznej wobec Azerbejdżanu realizował ambasador Michał Łabenda - arabista, absolwent uniwersytetu w Kazachstanie, doświadczony dyplomata pracujący uprzednio w Taszkiencie i Waszyngtonie. W swojej misji koncentrował się na dyplomacji publicznej, wykorzystując jej narzędzia do promowania Polski jako aktywnego twórcy unijnej polityki wschodniej i ważnego partnera dla Azerbejdżanu ${ }^{32}$. Kreowaniem wizerunku Polski jako atrakcyjnego partnera gospodarczego, tworzeniem zachęty dla inwestorów oraz pomocą w nawiązywaniu kontaktów gospodarczych zajmowały się Polska Agencja Informacji i Inwestycji Zagranicznych oraz „Portal Promocji Eksportu”. Podległa ministrowi gospodarki PAIiIZ organizowała seminaria ekonomiczne z udziałem przedstawicieli administracji rządowej i przedsiębiorców. Jedno z nich zostało poświęcone wsparciu administracji i dyplomacji obu państw dla rozwoju polsko-azerbejdżańskiej współpracy gospodarczej, handlowej i inwestycyjnej ${ }^{33}$. Możliwością bezpośredniego spotkania

30 Więcej informacji na temat wizyt prezydenta z lat 2007-2009 można znaleźć na portalach „Prezydent” i „Ambasada Rzeczypospolitej w Baku”.

31 Prezydent jedzie do Azerbejdżanu; będzie list intencyjny ws. ropy, „Puls Biznesu” [online], 1 VII 2009 [dostęp: 17 X 2019], dostępny w internecie: <https://www.pb.pl/ prezydent-jedzie-do-azerbejdzanu-bedzie-list-intencyjny-ws-ropy-506100>; L. Kaczyński o umowie gazowej między Rosją a Azerbejdżanem, „Puls Biznesu” [online], 3 VII 2009 [dostęp: 17 X 2019], dostępny w internecie: <https://www.pb.pl/l-kaczynski-oumowie-gazowej-miedzy-rosja-a-azerbejdzanem-506551>. W lutym 2008 r. prezydenci obu państw podpisali deklarację w sprawie bezpieczeństwa energetycznego oraz potwierdzili poparcie budowy korytarza tranzytowego dla kaspijskiej ropy w postaci projektu Odessa-Brody-Płock-Gdańsk.

32 „Biuletyn z posiedzenia Komisji Spraw Zagranicznych (nr 175)”...

33 Polsko-azerbejdżańskie seminarium ekonomiczne, „Polska Agencja Inwestycji i Handlu” [online], 7 VI 2011 [dostęp: 17 X 2019], dostępny w internecie: <https://www.paih.gov. p1/20110607/polsko_azerbejdzanskie_seminarium_ekonomiczne>. Seminarium stanowiło przygotowanie do wizyty prezydenta Bronisława Komorowskiego w Azerbejdżanie w lipcu 2011 r. Podczas prowadzonych wówczas rozmów z prezydentem Ilhamem Alijewem poruszano sprawy budowy obiektów przesyłowych ropy i gazu. Spotkanie prezydentów Polski i Azerbejdżanu, „Prezydent” [online], 25 VII 2011 [dostęp: 15 IX 2012], dostępny w internecie: <https://www.prezydent.pl/archiwum-bronislawa-komorowskiego/aktualnosci/wizyty-zagraniczne/art,101,spotkanie-prezydentow-polski-i-azerbejdzanu.htm>. 
z parterami biznesowymi z Azerbejdżanu była także wystawa $16^{\text {th }}$ Azerbaijan International Telecommunications and Information Technology Exibition, na której PAIiIZ zorganizowała polskie stoisko promocyjne ${ }^{34}$.

Wśród priorytetów polskiej polityki zagranicznej na lata 2012-2016 znalazły się: zaangażowanie w transformację ustrojową Europy Wschodniej i państw Kaukazu Południowego, wsparcie dla procesu stabilizacji i bezpieczeństwa w regionie, liberalizacja wizowa, utworzenie strefy wolnego handlu z krajami regionu oraz rozwój wymiany handlowej i relacji gospodarczych ${ }^{35}$. Warunkiem zwiększenia eksportu na rynki wschodnie było m.in. nakłonienie polskich przedsiębiorców do inwestowania w krajach regionu. Lata 2013-2014 przyniosły wyraźny wzrost wymiany handlowej między Polską a Azerbejdżanem, dlatego MG zwracało uwagę na potrzebę zwiększenia polskich inwestycji w tym kraju. Wzrost polskiego eksportu miał się stać lekiem na spowolnienie gospodarcze i z tego powodu eksport i inwestycje kapitałowe wspierano działaniami na szczeblu państwowym i rządowym. Spadek obrotów handlowych z Rosją w 2014 r. skłonił polski rząd do poszukiwania nowych rynków i przeznaczenia $5 \mathrm{mln}$ zł na promocję polskiego eksportu w jedenastu wybranych krajach ${ }^{36}$. W latach 2014-2015 minister gospodarki Janusz Piechociński dwukrotnie przebywał z misją w Azerbejdżanie, uczestnicząc wraz z polskimi przedsiębiorcami z branż transportowej, rolno-spożywczej, techniki rolnej i informatycznej w Forum Gospodarczym Polska-Azerbejdżan czy też zabierając do Baku przedstawicieli dużych firm, jak Asseco Poland, Tines, PGNiG, Gaz System, Lotos i Geofizyka Kraków ${ }^{37}$.

34 „Newsletter PAIiIZ” 2010, nr 191, dostępny w internecie [dostęp: 17 X 2019]: <https:// www.paih.gov.pl/index/?id=0a54b19a13b6712dc04d1b49215423d8\#14>. Przedsiębiorcy mogli uzyskać dofinansowanie uczestnictwa w targach w ramach Programu Operacyjnego „Innowacyjna Gospodarka 2007-2013”, poddziałania 6.5.1: „Promocja polskiej gospodarki na rynkach międzynarodowych".

35 Priorytety polskiej polityki zagranicznej 2012-2016, Ministerstwo Spraw Zagranicznych, Warszawa, marzec 2012, dostępny w internecie [dostęp: 17 X 2019]: <https://www. polskapomoc.gov.pl/download/files/Dokumenty_i_Publikacje/Priorytety_Polskiej_Polityki_Zagranicznej_2012-2016.pdf $>$.

36 B. Tomaszkiewicz, 11 nowych rynków dla polskiego eksportu. Rzad zachęca do inwestowania w Mongolii, Turkmenistanie czy Malezji, „INN Poland” [online], 27 XI 2014 [dostęp: 17 X 2019], dostępny w internecie: <https://innpoland.pl/113985, ministerstwogospodarki-rozpoczyna-nowa-promocje-polskich-wyrobow $>$.

37 Piechociński z roboczq wizyta w Azerbejdżanie, „Puls Biznesu” [online], 13 XII 2014 [dostęp: 17 X 2019], dostępny w internecie: <https://www.pb.pl/piechocinski-z-roboczawizyta-w-azerbejdzanie-777722>; Polska proponuje Azerbejdżanowi status obserwatora we Wspólnocie Energetycznej, „Onet” [online], 2 VI 2015 [dostęp: 4 X 2015], dostępny $\mathrm{w}$ internecie: <https://wiadomosci.onet.pl/swiat/polska-proponuje-azerbejdzanowi-statusobserwatora-we-wspolnocie-energetycznej/kqw7zx>. 
Zaproszenia do udziału w misjach zagranicznych kierowały do przedsiębiorców i przedstawicieli samorządu gospodarczego zarówno MSZ, jak i MG. Robiły to na swoich stronach internetowych lub przesyłając informacje do samorządów gospodarczych i jednostek samorządu terytorialnego. Niejednokrotnie jednak dublowały swoje działania i organizowały odrębne misje do Azerbejdżanu w tym samym roku. Poważnym niedopatrzeniem ministerstw było również zbyt późne powiadamianie o organizowanych misjach gospodarczych (na trzy tygodnie przez wyjazdem), na co zwróciła uwagę Najwyższa Izba Kontroli ${ }^{38}$.

Pomimo wielu działań promocyjno-handlowych podejmowanych w omawianym okresie współpraca inwestycyjno-kapitałowa między obydwoma państwami nie była intensywna. Głównym powodem nikłego zainteresowania polskich inwestorów były trudności w prowadzeniu działalności gospodarczej na rynku azerbejdżańskim. W 2010 r. wartość polskich inwestycji w tym kraju osiągnęła $1 \mathrm{mln}$ dol. i dopiero w latach 2012-2017 wzrosła do 17,72 mln dol. (chodzi tu wyłącznie o inwestycje niezwiązane z sektorem paliwowo-energetycznym) $)^{39}$. Z różnym skutkiem swoje interesy w Azerbejdżanie próbowały realizować takie polskie firmy, jak: Selena (chemia budowlana), APS Energia (energetyka, dostawy komponentów do sieci przesyłowych, współpraca z AzerEnerji), Hydrosprzęt (dystrybucja maszyn Huty Stalowa Wola), Tines, Polpharma, Inglot, Rafako, PKP LHS, PKP Cargo ${ }^{40}$.

Polska nie odgrywała w omawianym okresie znaczącej roli w wymianie handlowej Azerbejdżanu. W strukturze eksportu tego kraju wiodącym partnerem były Włochy, z udziałem 4,22 mld dol., podczas gdy eksport do Polski wynosił jedynie $12 \mathrm{mln}$ dol. Najważniejszym dostawcą na azerbejdżański rynek była Turcja (1,69 mld dol.), a import z Polski wynosił zaledwie $125 \mathrm{mln}$ dol. ${ }^{41}$ Największy udział w polskim eksporcie do Azerbejdżanu miały wyroby elektromaszynowe, artykuły rolno-spożywcze, wyroby z metali nieszlachetnych, produkty przemysłu chemicznego, środki transportu oraz zwierzęta i produkty pochodzenia zwierzęcego. Niskie obroty handlowe Polski z Azerbejdżanem utrzymywały się pomimo uznania tego kraju za rynek perspektywiczny

38 Promocja gospodarcza Polski. Informacja o wynikach kontroli, Najwyższa Izba Kontroli, Warszawa 2016, s. 37, dostępny w internecie [dostęp: 17 X 2019]: <https://www.nik.gov. pl/kontrole/wyniki-kontroli-nik/pobierz,kgp p_15_023_201510060940051444124405 01,typ,kk.pdf $>$.

39 Informacja uzyskana z Ambasady RP w Baku na zapytanie autorki, kwiecień $2018 \mathrm{r}$.

40 Informacja uzyskana z Ambasady RP w Baku na zapytanie autorki, kwiecień $2018 \mathrm{r}$.

41 Rynek dla eksportera - doradztwo Azerbejdżan, „East Analytics” [online, dostęp: 17 X 2019], dostępny w internecie: <http://eastanalytics.com/pl/doradztwo-azerbejdzan/>. 
dla polskiej gospodarki oraz stałego wzrostu udziału Polski w międzynarodowej wymianie handlowej. Były prezes PAIZ Sławomir Majman tłumaczył to słabą znajomością rynku i azerbejdżańskich przedsiębiorców, co świadczyłoby także o nieskutecznym systemie promocji polskiego eksportu i działań dyplomacji gospodarczej oraz niechęci polskich przedsiębiorstw do podejmowania ryzykownych działań na tamtym rynku ${ }^{42}$.

Tabela 1. Obroty handlowe Polski z Azerbejdżanem (mln dol.)

\begin{tabular}{|c|c|c|c|}
\hline Rok & Ogólem & Eksport & Import \\
\hline 2006 & 76,4 & 69,9 & 6,5 \\
\hline 2007 & 73,8 & 69,3 & 4,4 \\
\hline 2008 & 272,1 & 104,9 & 167,1 \\
\hline 2009 & 93,2 & 82,9 & 10,3 \\
\hline 2010 & 145,0 & 134,0 & 10,5 \\
\hline 2011 & 131,0 & 126,5 & 4,3 \\
\hline 2012 & 127,1 & 122,8 & 4,3 \\
\hline 2013 & 153,3 & 134,4 & 19,9 \\
\hline 2014 & 171,6 & 140,2 & 31,4 \\
\hline 2015 & 135,0 & 120,7 & 14,2 \\
\hline
\end{tabular}

Źródło: Handel zagraniczny, „Główny Urząd Statystyczny” [online, dostęp: 12 IV 2018], dostępny w internecie: $<$ https://stat.gov.pl/cps/rde/xbcr/gus/RS_rocznik_statystyczny_ handlu_zagranicznego.pdf $>$; Azerbejdżan, „Ministerstwo Spraw Zagranicznych” [online, dostęp: 17 X 2019], dostępny w internecie: <https://www.msz.gov.pl/pl/polityka_ zagraniczna/polityka_wschodnia/stosunki_dwustronne_polityka_wschodnia/azerbejdzan>; K. Gomółka, Wymiana..., s. 5-16

\section{Działania Ambasady RP w Baku w sferze dyplomacji ekonomicznej}

Od początku swego istnienia Ambasada RP w Baku nie dysponowała Wydziałem Ekonomiczno-Handlowym, tzn. jednostką, która w myśl założeń MSZ z 1999 r. odpowiadałaby za rozwój współpracy gospodarczej oraz

42 Wypowiedź prezesa PAIZ Sławomira Majmana w związku z wizytą ministra gospodarki Janusza Piechocińskiego w Baku, czerwiec 2015: Azerbejdżan to bardzo perspektywiczny rynek, „Money” [online], 3 VI 2015 [dostęp: 18 IV 2018], dostępny w internecie: $<$ http://biztok.money.pl/gospodarka/artykul/azerbejdzan-to-bardzo-perspektywiczny-rynek,80,0,1819216.html>. Dla porównania wymiana handlowa Azerbejdżanu z Czechami osiąga wartość 2 mld dol. Misja handlowa Azerbejdżan. Baku 2017 - listopad. 22-25.11.2017, Stowarzyszenie Współpracy Polska-Azerbejdżan, Polsko-Azerbejdżańska Rada Biznesu, [Warszawa 2017], dostępny w internecie [dostęp: 18 IX 2019]: $<$ https://www.trade.gov.pl/p1/f/download/fobject_id:439450>. 
promocję polskiego eksportu i polskich przedsiębiorstw ${ }^{43}$. Jak już wspomniano, także po przeprowadzonej w 2006 r. reformie, której celem była ekonomizacja polskiej służby zagranicznej, w strukturze bakijskiej ambasady nie powstał Wydział Promocji Handlu i Inwestycji. W lutym 2008 r. MSZ stworzyło średniookresową strategię rozwoju współpracy z wybranymi krajami rozwijającymi się (obejmującą Angolę, Azerbejdżan, Indonezję, Irak, Kazachstan, Libię, Turkmenistan, Wenezuelę, Wietnam i Zjednoczone Emiraty Arabskie), a ponadto opracowano raporty przedstawiające aktualną sytuację na rynkach tych państw oraz propozycje usunięcia barier dla handlowej i inwestycyjnej działalności polskich firm ${ }^{44}$. Pomimo zwiększenia zakresu obowiązków pracowników służby zagranicznej od 2014 r. nie było w polskiej placówce w Baku pracownika na etacie do spraw gospodarczych ${ }^{45}$. W tej sytuacji wszystkie zadania związane z promocją polskiej gospodarki spoczywały na pracownikach Wydziału Ekonomicznego (Polityczno-Ekonomicznego). Wydziały te realizowały $w$ ambasadach standardowe funkcje analityczne i informacyjne w zakresie współpracy handlowej i inwestycyjnej, działały na rzecz likwidacji barier w dostępie do rynków, budowały relacje gospodarcze z krajami i regionami priorytetowymi, organizowały wizyty i negocjacje rządowe, promowały polską gospodarkę, wspierały interesy polskich przedsiębiorców (zwłaszcza dużych firm państwowych) i opracowywały informacje makroekonomiczne na temat sytuacji gospodarczej w państwie przyjmującym ${ }^{46}$.

Działania dyplomacji ekonomicznej mają szczególne znaczenie w państwach, gdzie dominującą rolę w nawiązywaniu relacji biznesowych odgrywa administracja, dlatego zważywszy na niewielką obsadę kadrową wydziałów ekonomicznych ambasad RP i ich obciążenie pracą (zwłaszcza tam,

43 Azerbejdżan. Przewodnik..., s. 101; Rola Wydziałów Ekonomiczno-Handlowych ambasad i konsulatów w rozwoju wspótpracy gospodarczej Polski z pozaeuropejskimi krajami rozwijającymi się, „Serwis Polskich Eksporterów” [online], 5 II 2017 [dostęp: 17 X 2019], dostępny w internecie: <http://www.exporter.pl/bazy/Kraje/137.php>. Szerzej o pracy tych wydziałów zob.: E. Molendowski, W. Polan, Dyplomacja..., s. 16-193; E. Molendowski, Dyplomacja..., s. 456-457.

44 Promocja gospodarcza Polski...

45 Informacja uzyskana na mailowe zapytanie od pracownika Referatu Kaukazu Południowego Departamentu Wschodniego MSZ.

46 Odpowiedź podsekretarza stanu w Ministerstwie Spraw Zagranicznych [Henryki Mościckiej-Dendys] - z upoważnienia ministra - na interpelacje nr $18457 \mathrm{w}$ sprawie promocji polskiego biznesu i przedsiębiorczości przez ambasadora $w$ Republice Azerbejdżanu, „Sejm Rzeczypospolitej Polskiej” [online], 26 VII 2013 [dostęp: 17 X 2019], dostępny w internecie: <http://www.sejm.gov.pl/sejm7.nsf/InterpelacjaTresc. $\mathrm{xsp}$ ?key=1B6292D9>. 
gdzie nie funkcjonowały WPHI), realizacja powierzonych zadań stawała się trudna ${ }^{47}$. Takim państwem z pewnością jest Azerbejdżan, więc należałoby oczekiwać, że potencjał kadrowy polskiej ambasady powinien być większy. Na podstawie dostępnych informacji można tymczasem stwierdzić, że rezultaty działań placówki w Baku na rzecz promocji polskiej gospodarki nie były wystarczające. W przeciwieństwie do WPHI wydziały ekonomiczne nie zamieszczały informacji rynkowych czy analitycznych (choćby w postaci cyklicznych biuletynów) ani też nie dysponowały odrębnymi narzędziami dyplomacji cyfrowej (jak portal WPHI czy internetowa baza danych „Portalu Promocji Eksportu"). Na stronie internetowej ambasady w Baku brakowało aktualnych statystyk; dość wspomnieć, że jeszcze w połowie 2018 r. prezentowane były tam informacje ekonomiczne na temat wymiany handlowej w latach 2007-2012, bazujące na danych Głównego Urzędu Statystycznego i Azerbejdżańskiego Urzędu Statystycznego ${ }^{48}$. Przedsiębiorca zainteresowany podjęciem działalności w Azerbejdżanie w 2018 r. mógł znaleźć na stronie ambasady kilka biuletynów z lat $2010-2013^{49}$. Analiza zamieszczonych tam informacji wyraźnie pokazuje małe zainteresowanie placówki sprawami gospodarczymi i niewielką aktywność w sferze działań ekonomicznych, a należy podkreślić, że w 2012 r. krajem akredytacji polskiego ambasadora w Baku stał się także Turkmenistan, co jeszcze bardziej obciążało obowiązkami pracowników ambasady. Żaden biuletyn nie oferował analiz rynkowych

47 Odpowiedź ministra spraw zagranicznych [Anny Fotygi] - z upoważnienia prezesa Rady Ministrów - na interpelacje $n r 5816$ w sprawie zadań wydziałów ekonomicznych polskich placówek zagranicznych, realizowanych na rzecz organów państwa, „Sejm Rzeczypospolitej Polskiej” [online], 23 I 2007 [dostęp: 17 X 2019], dostępny w internecie: $<$ http://orka2.sejm.gov.p1/IZ5.nsf/main/67F970CC >. O roli polskich placówek dyplomatycznych otwierających drzwi współpracy gospodarczej mówił w sejmie szef dyplomacji Radosław Sikorski: Odpowiedź ministra spraw zagranicznych [Radosława Sikorskiego] na interpelację $n r 14588$ w sprawie konieczności stworzenia systemu promocji polskiej gospodarki $i$ wspierania za granica polskich przedsiębiorstw, „Sejm Rzeczypospolitej Polskiej” [online], 20 III 2013 [dostęp: 17 X 2019], dostępny w internecie: <http://www. sejm.gov.pl/sejm7.nsf/InterpelacjaTresc.xsp?key=12A169D7>; Materiat informacyjny na posiedzenie Komisji Gospodarki Narodowej... W Wydziale Polityczno-Ekonomicznym ambasady w Baku pracowało i nadal pracuje od trzech do pięciu osób (informacja uzyskana z ambasady RP w Baku, maj 2018).

48 Informator ekonomiczny Azerbejdżan. Wymiana dwustronna, „Ambasada Rzeczypospolitej Polskiej w Baku" [online, dostęp: 11 IV 2018], dostępny w internecie: <https://baku. msz.gov.pl/dyplomacja\%20ekonomiczna\%20i\%20Azernejd\%C5\%BCan/9.\%20Azerbejdzan.pdf>.

49 Biuletyny Ambasady RP w Baku, „Ambasada Rzeczypospolitej Polskiej w Baku” [online, dostęp: 17 X 2019], dostępny w internecie: <https://baku.msz.gov.pl/pl/o_ambasadzie/ ambasada/biuletyny/biuletyny?channel=www $>$. 
ułatwiających potencjalnym inwestorom i eksporterom poznanie rynku i warunków prowadzenia działalności. Odnotowano jedynie kilka informacji na temat przetargów i sprzedaży akcji azerbejdżańskich firm, możliwości inwestowania $\mathrm{w}$ sektorze kolejowym, informację na temat prezentacji polskich firm w ramach programu Green Evo oraz uczestnictwa ambasadora Michała Łabendy w seminarium ekonomicznym ${ }^{50}$. Zdecydowanie więcej działań podjęto w zakresie dyplomacji publicznej i kulturalnej, promującej polską historię, uczelnie wyższe, literaturę i sztukę $e^{51}$.

Wydział Ekonomiczny udzielał natomiast informacji na temat planowanych targów i wystaw. Sam też w nich współuczestniczył, organizując stoiska informacyjne, zgodnie z ustaleniami Porozumienia między Ministrem Spraw Zagranicznych a Ministrem Gospodarki w sprawie wspótpracy w realizacji zadań Ministra Gospodarki z zakresu promocji handlu i inwestycji zagranicznych przez polskie placówki zagraniczne, w których nie funkcjonuja Wydziały Promocji Handlu i Inwestycji z 14 września 2006 r. Na jego mocy wydziały ekonomiczne ambasad realizują zadania promocyjne poprzez przygotowywanie stoisk informacyjnych na targach i wystawach, organizację seminariów i spotkań, udzielanie informacji na temat warunków inwestowania w państwie akredytacji. Wszystkie te działania finansowane są ze środków $\mathrm{MG}^{52}$. Ambasada $\mathrm{w}$ Baku organizowała stoiska informacyjne podczas targów i wystaw, m.in. World Food w Baku 15-17 maja 2008 r. ${ }^{53}$

\section{Podsumowanie}

W prezentowanym materiale źródłowym oraz przywołanej literaturze przedmiotu dokonano już oceny zarówno dyplomacji ekonomicznej, jak i działań WPHI oraz systemu promocji polskiej gospodarki po 2006 r. Od lat powtarzały się w nich niemal zawsze te same konkluzje: konieczność podniesienia

50 „Biuletyn Ekonomiczny Ambasady RP w Baku” 2010, nr 6; 2011, nr 5; 2012, nr 2.

51 „Biuletyn Ekonomiczny Ambasady RP w Baku” 2011, nr 1; 2011, nr 2; 2013, nr 1.

52 Materiat informacyjny na posiedzenie Komisji Gospodarki Narodowej..., s. 1. W latach 2010-2015 przynajmniej jednokrotnie działania promocyjne na zlecenie Ministerstwa Gospodarki podjęło 37 placówek dyplomatycznych, w których nie było WPHI. Łączny koszt tych przedsięwzięć wyniósł $4 \mathrm{mln}$ zł. Promocja gospodarcza Polski... Na podstawie tego raportu powstało opracowanie: S. Grzelak, Promocja gospodarcza Polski, „Kontrola Państwowa” 2017, nr 2, s. 82-94.

53 Polskie stoisko na wystawie World Food, „Ambasada Rzeczypospolitej Polskiej w Baku” [online], $30 \mathrm{~V} 2008$ [dostęp: 17 X 2019], dostępny w internecie: <https://baku.msz.gov. $\mathrm{pl} / \mathrm{pl} /$ aktualnosci/archiwum/2008/>. 
efektywności działań dyplomacji ekonomicznej, utworzenia spójnego systemu i jednej instytucji odpowiedzialnej za realizację działań na rzecz współpracy gospodarczej, promocji polskiego eksportu i inwestycji za granicą. Wydaje się także, kluczowym warunkiem skutecznego działania systemu jest zwiększenie obsady kadrowej i jej profesjonalizacja oraz podniesienie nakładów finansowych na te działania (do tej pory nie były one zbyt wysokie - w latach 2012-2015 na promocję polskiej gospodarki wydano $368 \mathrm{mln} \mathrm{z}^{54}$ ). Wdrażany od dwóch lat system promocji gospodarczej, którego osią mają być działania Polskiej Agencji Handlu i Inwestycji, jest dopiero tworzony. Na razie doprowadził do likwidacji dotychczasowych struktur, powstania zagranicznych biur handlowych oraz głębokich zmian kadrowych. 2 lipca 2018 r. utworzono w Baku Zagraniczne Biuro Handlowe, które od 1 października zatrudnia... dwóch pracowników.

Działania polskiej dyplomacji gospodarczej wobec Azerbejdżanu cechują poważne słabości, zwłaszcza na poziomie struktur, za które odpowiada MSZ. Współpraca gospodarcza z krajem uznanym za ważnego partnera jest stosunkowo słaba, a problematyka ekonomiczna w analizowanych latach 2006-2015 nie była priorytetowym obszarem działania Ambasady RP w Baku. Ekonomizacja polskiej polityki zagranicznej miała doprowadzić do zwiększenia roli problematyki gospodarczej w działaniach dyplomacji, tymczasem w strukturze polskiej ambasady w Baku nie było WPHI, brakowało profesjonalnej kadry, WE włączono do Wydziału Polityczno-Ekonomicznego, a strona internetowa placówki nie tylko nie zachęcała inwestorów i eksporterów, ale nawet nie zawierała aktualnych informacji o warunkach działania na azerbejdżańskim rynku. Zasady współpracy podmiotów odpowiedzialnych za prowadzenie operacyjnej działalności promocyjno-handlowej realizowano co prawda poprawnie, za pomocą takich narzędzi jak misje gospodarcze i handlowe czy udział w seminariach ekonomicznych i targach, ale ich skuteczność była mniejsza, niż się spodziewano, na co wpływały także trudne warunki funkcjonowania podmiotów gospodarczych na niepewnym rynku Azerbejdżanu.

Zasadniczym postulatem badawczym pozostaje przeprowadzenie empirycznych badań oraz analiz efektów pracy służb odpowiedzialnych za promocję Polski i rozwój jej współpracy gospodarczej tak, aby możliwa stała się ocena tej działalności, a co za tym idzie - właściwy dobór narzędzi realizacji

54 I. Antoniszyn-Klik, K. Kacperczyk, Promocja gospodarcza i wsparcie przedsiębiorstw na rynkach zagranicznych 2013-2014, [Warszawa 2014], dostępny w internecie [dostęp: 17 X 2019]: <http://ekb.org.pl/ekb/wp-content/uploads/2014/05/Promocja-gospodarczai-wsparcie-przedsi\%C4\%99biorstw-na-rynkach-zagranicznych-2013-2014.ppt>. 
ekonomicznych interesów państwa. Niestety, nie stworzono jak dotąd mechanizmów i metodologii badań pozwalających ocenić skuteczność działań podmiotów odpowiedzialnych za promocję polskiej gospodarki, poza kilkoma wskaźnikami: zadowoleniem firm biorących udział w misjach, liczbą odsłon na portalach informacyjnych czy statystyką zorganizowanych wydarzeń ${ }^{55}$. Kompleksowa analiza efektywności i skuteczności w latach 2010-2015 dokonana została przez Najwyższą Izbę Kontroli jedynie na podstawie sprawozdań z tych jednostek.

\section{Bibliografia}

\section{Źródta}

„Biuletyn z posiedzenia Komisji Spraw Zagranicznych (nr 153)” 2001, nr 4096/III kad., dostępny w internecie [dostęp: $17 \mathrm{X}$ 2019]: <http://orka.sejm.gov.pl/Biuletyn.nsf/0/ 84E45CC9D767E5B9C1256B73003DD103?OpenDocument>.

„Biuletyn z posiedzenia Komisji Spraw Zagranicznych (nr 175)” 2010, nr 3974/VI kad., dostępny w internecie [dostęp: 17 X 2019]: <http://orka.sejm.gov.pl/Biuletyn.nsf/o/ A6C3B845717FBCD3C125776900483C27/\$file/0397406.pdf>.

„Biuletyn z posiedzenia Komisji Spraw Zagranicznych (nr 238)” 2005, nr 4465/IV kad., dostępny w internecie [dostęp: $17 \mathrm{X}$ 2019]: <http://orka.sejm.gov.pl/Biuletyn.nsf/0/ 32153D16D280A7C0C1256FF8003ED1BB?OpenDocument>.

Dyplomacja ekonomiczna. Pierwszy rok działania, Departament Zagranicznej Polityki Ekonomicznej MSZ, Warszawa, czerwiec 2007.

Odpowiedź ministra spraw zagranicznych [Anny Fotygi] - $z$ upoważnienia prezesa Rady Ministrów - na interpelacje $\mathrm{nr} 5816 \mathrm{w}$ sprawie zadań wydziatów ekonomicznych polskich placówek zagranicznych, realizowanych na rzecz organów państwa, „Sejm Rzeczypospolitej Polskiej” [online], 23 I 2007 [dostęp: 17 X 2019], dostępny w internecie: $<$ http://orka2.sejm.gov.pl/IZ5.nsf/main/67F970CC > .

Odpowiedź ministra spraw zagranicznych [Radosława Sikorskiego] na interpelację $n r 14588$ w sprawie konieczności stworzenia systemu promocji polskiej gospodarki $i$ wspierania za granica polskich przedsiębiorstw, „Sejm Rzeczypospolitej Polskiej” [online], 20 III 2013 [dostęp: 17 X 2019], dostępny w internecie: <http://www.sejm.gov.pl/sejm7.nsf/ InterpelacjaTresc.xsp?key=12A169D7>.

Odpowiedź podsekretarz stanu w Ministerstwie Gospodarki [Ilony Antoniszyn-Klik] - z upoważnienia ministra - na interpelację poselska $n r 14588$ w sprawie konieczności stworzenia systemu promocji polskiej gospodarki $i$ wspierania za granica polskich przedsiębiorstw,

55 Promocja gospodarcza Polski...; Promocja polskiej gospodarki za granica, Polski Instytut Spraw Międzynarodowych, Warszawa 2014, dostępny w internecie [dostęp: 17 X 2019]: <http://docplayer.pl/17631243-Promocja-polskiej-gospodarki-za-granica.html>. Por. S.J.V. Moons, P.A.G. van Bergeijk, Does economic diplomacy work? A meta-analysis of its impact on trade and investment, „The World Economy” 2017, vol. 40, issue 2, s. 336-368, dostępny w internecie [dostęp: 17 X 2019]: <https://onlinelibrary.wiley.com/ doi/abs/10.1111/twec.12392>. 
„Sejm Rzeczypospolitej Polskiej” [online], 13 III 2013 [dostęp: 17 X 2019], dostępny w internecie: $<$ http://www.sejm.gov.pl/sejm7.nsf/InterpelacjaTresc.xsp?key=4EB50AD6>. Odpowiedź podsekretarza stanu w Ministerstwie Spraw Zagranicznych [Henryki Mościckiej-Dendys] - z upoważnienia ministra - na interpelację nr 18457 w sprawie promocji polskiego biznesu i przedsiębiorczości przez ambasadora w Republice Azerbejdżanu, „Sejm Rzeczypospolitej Polskiej” [online], 26 VII 2013 [dostęp: 17 X 2019], dostępny w internecie: <http://www.sejm.gov.pl/sejm7.nsf/InterpelacjaTresc.xsp?key=1B6292D9>.

Porozumienia z 7 lutego 2006 r. między Ministrem Spraw Zagranicznych a Ministrem Gospodarki w sprawie ustanowienia dyplomacji ekonomicznej, „Biuletyn Prasowy” (Ministerstwo Gospodarki) 2006, nr 7.

Porozumienia z 14 września 2006 r. między Ministrem Spraw Zagranicznych a Ministrem Gospodarki w sprawie wspótpracy w realizacji działań Ministra Gospodarki z zakresu promocji handlu i inwestycji zagranicznych przez polskie placówki zagraniczne, w których nie funkcjonuja Wydziały Promocji Handlu i Inwestycji, „Biuletyn Prasowy” (Ministerstwo Gospodarki) 2006, nr 7.

Priorytety polskiej polityki zagranicznej 2012-2016, Ministerstwo Spraw Zagranicznych, Warszawa, marzec 2012, dostępny w internecie [dostęp: 17 X 2019]: <https://www.polskapomoc.gov.pl/download/files/Dokumenty_i_Publikacje/Priorytety_Polskiej_Polityki_ Zagranicznej_2012-2016.pdf $>$.

Promocja gospodarcza Polski. Informacja o wynikach kontroli, Najwyższa Izba Kontroli, Warszawa 2016, dostępny w internecie [dostęp: 17 X 2019]: <https:/www.nik.gov.pl/kontrole/wyniki-kontroli-nik/pobierz,kgp p_15_023_201510060940051444124405 01,typ,kk.pdf>.

Rozporzadzenie Ministra Gospodarki i Pracy z 15 października 2004 r. w sprawie pomocy de minimis przedsiębiorcom uczestniczacym $w$ targach $i$ wystawach za granica, Dz.U. 2004, nr 233, poz. 2342.

„Solidarne Państwo”. Program działania rząu premiera Kazimierza Marcinkiewicza, Warszawa 2005.

Ustawa z dnia 7 lipca 2017 r. o wykonywaniu zadań z zakresu promocji gospodarki przez Polska Agencję Inwestycji i Handlu Spółka Akcyjna, Dz.U. 2017, poz. 1491.

Założenia do Strategii Promocji Gospodarki Polskiej 2007-2015, Ministerstwo Gospodarki, Warszawa 2007.

\section{Prasa}

Azerbejdżan to bardzo perspektywiczny rynek, „Money” [online], 3 VI 2015 [dostęp: 18 IV 2018], dostępny w internecie: <http://biztok.money.pl/gospodarka/artykul/azerbejdzan-to-bardzo-perspektywiczny-rynek,80,0,1819216.html>.

„Biuletyn Ekonomiczny Ambasady RP w Baku” 2010, nr 6; 2011, nr 1; 2011, nr 2; 2011, nr 5; 2012, nr 2; 2013, nr 1.

„Biuletyn Prasowy Ministerstwa Gospodarki” 2007, nr 65.

L. Kaczyński o umowie gazowej między Rosja a Azerbejdżanem, „Puls Biznesu” [online], 3 VII 2009 [dostęp: 17 X 2019], dostępny w internecie: <https://www.pb.pl/ 1-kaczynski-o-umowie-gazowej-miedzy-rosja-a-azerbejdzanem-506551>.

MG: Azerbejdżan chce wspótpracować z Polska w dziedzinie gospodarki, „Puls Biznesu” [online], 10 IV 2006 [dostęp: 17 X 2019], dostępny w internecie: <https://www.pb.pl/ mg-azerbejdzan-chce-wspolpracowac-z-polska-w-dziedzinie-gospodarki-310205>. 
Piechociński z robocza wizyta w Azerbejdżanie, „Puls Biznesu” [online], 13 XII 2014 [dostęp: 17 X 2019], dostępny w internecie: <https://www.pb.pl/piechocinski-z-roboczawizyta-w-azerbejdzanie-777722>.

Prezydent jedzie do Azerbejdżanu; będzie list intencyjny ws. ropy, „Puls Biznesu” [online], 1 VII 2009 [dostęp: 17 X 2019], dostępny w internecie: <https://www.pb.pl/prezydentjedzie-do-azerbejdzanu-bedzie-list-intencyjny-ws-ropy-506100>.

Spotkanie prezydentów Polski i Azerbejdżanu, „Prezydent” [online], 25 VII 2011 [dostęp: 15 IX 2012], dostępny w internecie: <https://www.prezydent.pl/archiwum-bronislawa-komorowskiego/aktualnosci/wizyty-zagraniczne/art,101,spotkanie-prezydentow-polski-i-azerbejdzanu.htm>.

Zabłocki M., Polska i Azerbejdżan zwiększq handel, „Bankier” [online], 3 VI 2015 [dostęp: 17 X 2019], dostępny w internecie: <https://www.bankier.pl/wiadomosc/Polska-iAzerbejdzan-zwieksza-handel-3354958.html>.

\section{Opracowania}

Alijewa S., Partnerstwo strategiczne Republiki Azerbejdżanu i Rzeczypospolitej Polskiej, [w:] Materiały III konferencji naukowej poświęconej 540-leciu nawiązania oraz 20-leciu odnowienia stosunków dyplomatycznych między Azerbejdżanem a Polską, Oficyna „Olszynka”, Warszawa 2014.

Augustynowicz O., Bartosik-Purgat M., Rola placówek ekonomiczno-dyplomatycznych w dziatalności eksportowej polskich przedsiębiorstw - perspektywa placówek i przedsiębiorstw, „Handel Zagraniczny” 2015, nr 5.

Azerbejdżan. Przewodnik dla przedsiębiorców, oprac. A. Naruniec, E. Fischer, Biuro Promocji Inwestycji i Technologii Organizacji Narodów Zjednoczonych ds. Rozwoju Przemysłowego UNIDO, Warszawa 2006.

Chodubski A.J., Azerbejdżan - Polska. Odstony kontaktów kulturowych, Wydawnictwo „Adam Marszałek", Torun 2015.

Dumała H., Dyplomacja ekonomiczna - założenia i realizacja, [w:] Nowe oblicza dyplomacji, red. B. Surmacz, Wydawnictwo Uniwersytetu Marii Curie-Skłodowskiej, Lublin 2013.

Dylematy polityki zagranicznej Polski na początku XXI wieku, red. K. Czornik, M. Lakomy, M. Stolarczyk, Wydawnictwo Uniwersytetu Śląskiego, Katowice 2014.

Ekonomia 12 - problemy globalizacji, red. J. Rymarczyk, Wydawnictwo Uniwersytetu Ekonomicznego we Wrocławiu, Wrocław 2010.

Ford C., Commercial diplomacy. The next wave, „Foreign Service Journal” 2005, vol. 82 (2).

Gawin G., Kształtowanie się i rola dyplomacji ekonomicznej w Polsce, „Polski Przegląd Dyplomatyczny" 2008, nr 3 (43).

Gomółka K., Wymiana handlowa Polski z Armenią, Azerbejdżanem i Gruzja, „Acta Politica” 2014, nr 29.

Grzelak S., Promocja gospodarcza Polski, „Kontrola Państwowa” 2017, nr 2.

Handel zagraniczny i biznes międzynarodowy we współczesnej gospodarce, red. M. Maciejewski, K. Wach, Wydawnictwo Naukowe Uniwersytetu Ekonomicznego w Krakowie, Kraków 2017.

Hryniewiecki R., Borońska K., Dyplomacja gospodarcza jako nowe narzędzie polityki zagranicznej państwa, [w:] Ekonomia 12 - problemy globalizacji, red. J. Rymarczyk, Wydawnictwo Uniwersytetu Ekonomicznego we Wrocławiu, Wrocław 2010, dostępny w internecie [dostęp: 17 X 2019]: <https://www.academia.edu/5070783/Dyplomacja_ 
gospodarcza_jako_narz\%C4\%99dzie_polityki_zagranicznej_pa\%C5\%84stwa_2011_ Ekonomia_12_Problemy_globalizacji?auto=download $>$.

Materiaty III konferencji naukowej poświęconej 540-leciu nawiązania oraz 20-leciu odnowienia stosunków dyplomatycznych między Azerbejdżanem a Polska, Oficyna „Olszynka”, Warszawa 2014.

Molendowski E., Dyplomacja gospodarcza Polski: organizacja, główne zadania w okresie transformacji, [w:] Handel zagraniczny i biznes międzynarodowy we wspótczesnej gospodarce, red. M. Maciejewski, K. Wach, Wydawnictwo Naukowe Uniwersytetu Ekonomicznego w Krakowie, Kraków 2017, dostępny w internecie [dostęp: 17 X 2019]: $<$ https:/www.researchgate.net/publication/322405623_Dyplomacja_gospodarcza_Polski_ organizacja_glowne_zadania_w_okresie_transformacji>.

Molendowski E., Polan W., Dyplomacja gospodarcza - rola i znaczenie w polityce zagranicznej państwa, Wolters Kluwer Polska, Warszawa 2007.

Moons S.J.V., Bergeijk P.A.G. van, Does economic diplomacy work? A meta-analysis of its impact on trade and investment, ,The World Economy” 2017, vol. 40, issue 2, dostępny w internecie [dostęp: 17 X 2019]: <https://onlinelibrary.wiley.com/doi/abs/10.1111/twec.12392>.

Nowe oblicza dyplomacji, red. B. Surmacz, Wydawnictwo Uniwersytetu Marii Curie-Skłodowskiej, Lublin 2013.

Pinder J., Economic diplomacy, [w:] World politics. An introduction, ed. J.N. Rosenau, K.W. Thompson, G. Boyd, New York 1976.

Promocja polskiej gospodarki za granica, Polski Instytut Spraw Międzynarodowych, Warszawa 2014, dostępny w internecie [dostęp: 17 X 2019]: <http://docplayer.pl/17631243-Promocja-polskiej-gospodarki-za-granica.html>.

Przeperski M., Ostatnia próba modernizacji PRL. Rząd Mieczysława F. Rakowskiego (1988-1989), „Pamięć i Sprawiedliwość” 2016, nr 1 (27).

Różnice kulturowe w międzynarodowych relacjach biznesowych, Departament Współpracy Ekonomicznej Ministerstwa Spraw Zagranicznych, Warszawa 2017, dostępny w internecie [dostęp: 17 X 2019]: <https://www.msz.gov.pl/pl/p/msz_pl/polityka_zagraniczna/dyplomacja_biznes/wydarzenia/informator_o_roznicach_kulturowych_w_miedzynarodowych_relacjach_biznesowych?channel=www $>$.

Saner R., Yiu L., International economic diplomacy. Mutations in Post-modern times, „Clingendael Discussion Papers in Diplomacy” 2003, No. 84, dostępny w internecie [dostęp: 17 X 2019]: <https://www.clingendael.org/publication/international-economicdiplomacy-mutations-post-modern-times $>$.

Stosunki dyplomatyczne Polski. Informator, t. 3: Azja, Zakaukazie, Australia, Oceania 1918-2009, red. K. Szczepanik, A. Herman-Łukasik, B. Janicka, Akson, Warszawa 2010.

Surmacz B., Ewolucja wspótczesnej dyplomacji. Aktorzy, struktury, funkcje, Wydawnictwo Uniwersytetu Marii Curie-Skłodowskiej, Lublin 2015.

Szczepanik K., Dyplomacja Polski 1918-2000-struktury organizacyjne, Akson, Warszawa 2000. Szczepańska A., Dyplomacja ekonomiczna Polski 2006-2008, [w:] W kręgu idei, polityki i wojska. Studia dedykowane Profesorowi Januszowi Farysiowi w siedemdziesiąta rocznice urodzin, red. T. Sikorski, H. Walczak, A. Wątor, Wydawnictwo Naukowe Uniwersytetu Szczecińskiego, Szczecin 2009.

Szczepańska-Dudziak A., Dyplomacja ekonomiczna Polski na Wschodzie, [w:] Dylematy polityki zagranicznej Polski na początku XXI wieku, red. K. Czornik, M. Lakomy, M. Stolarczyk, Wydawnictwo Uniwersytetu Śląskiego, Katowice 2014. 
W kręgu idei, polityki i wojska. Studia dedykowane Profesorowi Januszowi Farysiowi w siedemdziesiąta rocznice urodzin, red. T. Sikorski, H. Walczak, A. Wątor, Wydawnictwo Naukowe Uniwersytetu Szczecińskiego, Szczecin 2009.

World politics. An introduction, ed. J.N. Rosenau, K. W. Thompson, G. Boyd, New York 1976. Zasztowt K., Azerbejdżan po dekadzie rządów prezydenta Ilhama Aliyeva, Polski Instytut Spraw Międzynarodowych, 4 IX 2013 (Biuletyn PISM, 90 (1066)).

Zerka P., Instrumentarium dyplomacji ekonomicznej: wyzwania i dylematy. Materiat na trzecie spotkanie z serii „Polska w świecie 2030. Globalizacja polskiej polityki zagranicznej i europejskiej”, Demos Europa, [Warszawa] 2012.

\section{Źródla internetowe}

Antoniszyn-Klik I., Kacperczyk K., Promocja gospodarcza i wsparcie przedsiębiorstw na rynkach zagranicznych 2013-2014, [Warszawa 2014], dostępny w internecie [dostęp: 17 X 2019]: $<$ http://ekb.org.pl/ekb/wp-content/uploads/2014/05/Promocja-gospodarcza-i-wsparcieprzedsi\%C4\%99biorstw-na-rynkach-zagranicznych-2013-2014.ppt>.

Azerbejdżan, „Ministerstwo Spraw Zagranicznych” [online, dostęp: 17 X 2019], dostępny w internecie: <https://www.msz.gov.pl/pl/polityka_zagraniczna/polityka_wschodnia/stosunki_dwustronne_polityka_wschodnia/azerbejdzan>.

Biuletyny Ambasady RP w Baku, „Ambasada Rzeczypospolitej Polskiej w Baku” [online, dostęp: 17 X 2019], dostępny w internecie: <https://baku.msz.gov.pl/pl/o_ambasadzie/ ambasada/biuletyny/biuletyny?channel=www $>$.

Handel zagraniczny, „Główny Urząd Statystyczny” [online, dostęp: 12 IV 2018], dostępny w internecie: <https://stat.gov.pl/cps/rde/xbcr/gus/RS_rocznik_statystyczny_handlu_zagranicznego.pdf $>$.

Informacje praktyczne dla polskiego eksportera - Azerbejdżan, „Portal Promocji Eksportu” [online], 18 VIII 2017 [dostęp: 21 III 2018], dostępny w internecie: <https://www.trade.gov. $\mathrm{pl} / \mathrm{pl}$ /analizy-rynkowe/azja/azerbejdzan/227549, informacje-praktyczne-dla-polskiegoeksportera-azerbejdzan.html>.

Informator ekonomiczny Azerbejdżan. Wymiana dwustronna, „Ambasada Rzeczypospolitej Polskiej w Baku" [online, dostęp: 11 IV 2018], dostępny w internecie: <https://baku.msz.gov. $\mathrm{pl} /$ dyplomacja\%20ekonomiczna\%20i\%20Azernejd\%C5\%BCan/9.\%20Azerbejdzan.pdf $>$.

Materiat informacyjny na posiedzenie Komisji Gospodarki Narodowej Senatu RP w sprawie efektywności promowania gospodarki w świecie. Informacja o działaniach MSZ na rzecz wzmocnienia wizerunku gospodarczego kraju za granica, Departament Dyplomacji Ekonomicznej MSZ, [Warszawa 2009], dostępny w internecie [dostęp: 14 VII 2014]: $<\mathrm{http}: / / \mathrm{ww} 2$.senat.p1/k7/kom/kgn/g/8.pdf $>$.

Misja handlowa Azerbejdżan. Baku 2017 - listopad. 22-25.11.2017, Stowarzyszenie Współpracy Polska-Azerbejdżan, Polsko-Azerbejdżańska Rada Biznesu, [Warszawa 2017], dostępny w internecie [dostęp: 18 IX 2019]: <https://www.trade.gov.pl/pl/f/ download/fobject_id:439450>.

„Newsletter PAIiIZ” 2010, nr 191, dostępny w internecie [dostęp: 17 X 2019]: <https://www. paih.gov.pl/index/?id=0a54b19a13b6712dc04d1b49215423d8\#14>.

Polska proponuje Azerbejdżanowi status obserwatora we Wspólnocie Energetycznej, „Onet” [online], 2 VI2015 [dostęp: 4 X 2015], dostępny w internecie: $<$ https://wiadomosci.onet.pl/swiat/polska-proponuje-azerbejdzanowi-status-obserwatora-we-wspolnocie-energetycznej/kqw7zx>. 
Polska Wystawa Narodowa w Azerbejdżanie, „Ambasada Rzeczypospolitej Polskiej w Baku” [online], 23 XII 2006 [dostęp: 17 X 2019], dostępny w internecie: <https://baku.msz.gov. $\mathrm{pl} / \mathrm{pl} / /$ aktualnosci/archiwum/2006/>.

Polskie stoisko na wystawie World Food, „Ambasada Rzeczypospolitej Polskiej w Baku” [online], 30 V 2008 [dostęp: 17 X 2019], dostępny w internecie: <https://baku.msz.gov.pl/pl/ aktualnosci/archiwum/2008/>.

Polsko-azerbejdżańskie seminarium ekonomiczne, „Polska Agencja Inwestycji i Handlu” [online], 7 VI 2011 [dostęp: 17 X 2019], dostępny w internecie: <https://www.paih.gov. p1/20110607/polsko_azerbejdzanskie_seminarium_ekonomiczne $>$.

Raport roczny za rok 2006, ,KUKE” [online, dostęp: 15 VII 2008], dostępny w internecie: $<\mathrm{http}$ ://www.kuke.com.pl/raport_roczny/ch_05_pl.html $>$.

Rola i zaangażowanie instytucji publicznych w promocję gospodarcza Polski i regionów (wystapienie R. Wiśniewskiego, Wiceministra SZ RP), dostępne w internecie [dostęp: $17 \mathrm{X}$ 2019]: <https://www.paih.gov.pl/files/?id_plik=7520>.

Rola Wydziałów Ekonomiczno-Handlowych ambasad i konsulatów w rozwoju wspótpracy gospodarczej Polski z pozaeuropejskimi krajami rozwijającymi się, „Serwis Polskich Eksporterów" [online], 5 II 2017 [dostęp: 17 X 2019], dostępny w internecie: <http:// www.exporter.pl/bazy/Kraje/137.php>.

Rynek dla eksportera - doradztwo Azerbejdżan, „East Analytics” [online, dostęp: 17 X 2019], dostępny w internecie: $<$ http://eastanalytics.com/pl/doradztwo-azerbejdzan/>.

Stosunki dwustronne, „Ambasada Republiki Azerbejdżanu w Rzeczypospolitej Polskiej” [online], 29 II 2016 [dostęp: 17 X 2019], dostępny w internecie: <http://warsaw.mfa.gov.az/ $\mathrm{pl} /$ content/3>.

Tomaszkiewicz B., 11 nowych rynków dla polskiego eksportu. Rząd zachęca do inwestowania $w$ Mongolii, Turkmenistanie czy Malezji, „INN Poland” [online], 27 XI 2014 [dostęp: 17 X 2019], dostępny w internecie: <https://innpoland.pl/113985, ministerstwo-gospodarki-rozpoczyna-nowa-promocje-polskich-wyrobow $>$.

Wizyta Marszalka Senatu RP w Azerbejdżanie „Ambasada Rzeczypospolitej Polskiej w Baku” [online], 23 XII 2006 [dostęp: 17 X 2019], dostępny w internecie: <https://baku.msz.gov. $\mathrm{pl} / \mathrm{pl} / /$ aktualnosci/archiwum/2006/>.

Wspieranie eksportu, rynki zagraniczne, „Eksporter” [online, dostęp: 14 VII 2008], dostępny w internecie: $<$ www.eksporter.gov.pl>. 